Ann. Biol. anim. Bioch. Biophys., 1979, 19 (3 B), 843-848.

\title{
The influence of bovine pancreatic polypeptide on pancreatic exocrine secretion in young calves
}

\author{
Marie-Jeanne DAVICCO, J. LEFAIVRE *, J.-P. BARLET \\ with the technical assistance of R. DABERT, Bernadetfe LASSALAS * and R. ROUX \\ Laboratoire des Maladies Métaboliques \\ * Laboratoire de la Digestion des Ruminants \\ I. N. R. A., Theix, St-Genès-Champanelle, \\ 63110 Beaumont.
}

\begin{abstract}
Summary. Two successive experiments were carried out on five 20 to 30 day old male Holstein $\times$ Frisian calves, weighing $66 \pm 6 \mathrm{~kg}$ and fed a milk replacer. These animals were fitted with a return cannula loop, chronically implanted at 10 days of age on the pancreatic duct, and were fasted $16 \mathrm{hrs}$. before each injection was begun. In experiment l, intravenous infusion of BPP $(10 \mu \mathrm{g} / \mathrm{kg} \mathrm{b} . \mathrm{w} . / \mathrm{hr}$ for $15 \mathrm{~min}$.) caused a significant decrease of pancreatic flow $(-51+11$ p. 100), and of the excretion of prot sins $(-75+10$ p. 100), amylase (-51 \pm 9 p. 100) and calcium (-54 \pm 15 p. 100) in the pancreatic juice between the 15 th and 30 th minute after the infusion was withdrawn. In experiment II, carried out on the same animals 5 days after the first one, the same dose of BPP, given by i.v. route between the 15th and 30th minute of an i.v. infusion of secretin (1.5 lvy Dog Unit/kg/hr for $105 \mathrm{~min}$.) significantly inhibited the pancreatic sezretion of water, proteins and amylase induced by secretin. During these two experiments, BPP showed no significant effect on glycemia.
\end{abstract}

\section{Introduction.}

Pancreatic polypeptide (PP) is a new hormone, first isolated from the avian pancreas (Kimmel, Pollock and Hazelwood, 1971), and later identified in several mammalian species, including humans, sheep and oxen (Lin and Chance, 1974). Bovine pancreatic polypeptide (BPP) is a linear polypeptide containing 36 amino acid residues (Lin, Chance and Evans, 1973 ; Lin et al., 1977).

Specific antisera were used to determine pancreatic polypeptide immunoreactivity, localized in a population of pancreatic endocrine cells which are distinct from insulin, glucagon or somatostatin cells in most mammals (Larsson, Sundler and Hakanson, 1976 ; Schweisthal, Schweisthal and Frost, 1978). PP cells in sheep are very numerous; they are scattered in some islets, and concentrated at one pole in others. A fair number of PP cells have been found in cows at the periphery of most islets. Extrainsular PP cells are occasionally observed in both sheep and cows (Larsson, Sundler and Hakanson, 1976). 
Until now, nobody, to our knowledge, has tried to determine the possible physiological role of BPP in the bovine species. In this report, we have studied the influence of an intravenous infusion of this hormone on pancreatic exocrine secretion in young calves.

\section{Materiel and methods.}

Five male Holstein $\times$ Frisian calves weighing $66 \pm 6 \mathrm{~kg}$ were used.

Surgery and sampling of pancreatic juice. - At the age of 10 to 12 days, the pancreafic duct of each animal was chronically catheterized with a return cannula loop, according to a technique previously described (McCormick and Stewart, 1967 ; Davicco, 1978). Under halothane anesthesia, the pancreatic duct was isolated and $2 \mathrm{~mm}$ of it longitudinally cut near the duodenal opening. 10 to $12 \mathrm{~mm}$ of a polyvinyl-chloride catheter (external diameter : $2.5 \mathrm{~mm}$; internal diameter : $1.5 \mathrm{~mm}$ ) was inserted into this duct towards the pancreas; another similar catheter was firmly attached to the duct. The two catheters were connected outside by a rubber tube when pancreatic secretion was not being collected. Such a catheterization allowed us to infuse the pancreatic juice into the duodenal branch of the catheter during periods of pancreatic juice collection at the flow rate measured during sampling, which avoided disturbing the feed-back regulation of the exocrine pancreas by pancreatic enzymes released in the intestine (Corring, 1974 ; Davicco, 1978).

The calves were fed a milk replacer (Olivot-Sarb: $130 \mathrm{~g}$ powder $/ \mathrm{kg}$ water ; $8 \mathrm{~kg} /$ animal $/$ day). During the first neonatal month, the mean daily weight gain of the animals was $995+240 \mathrm{~g}$. Pancreatic juice was collected for $15 \mathrm{~min}$. periods in tubes kept at $4^{\circ} \mathrm{C}$ in an ice-bath, and its volume was measured. A $3 \mathrm{ml}$ fraction of each sampling was frozen for enzymatic and mineral analyses.

Hormonal infusions. - In two successive experiments we observed the influence of an intravenous infusion of BPP, given alone or simultaneously with secretin.

- Experiment l. Basal pancreatic secretion was collected for at least $1 \mathrm{hr}$. before initiation of BPP infusion, while saline $(0.9$ p. $100 \mathrm{NaCl})$ was infused at a rate of $40 \mathrm{ml} / \mathrm{hr}$. into the jugular vein. BPP (Eli Lilly Laboratories, lot 615-D63-166-7) was then added to the saline at a dose of $10 \mu \mathrm{g} / \mathrm{kg} / \mathrm{hr}$. and infused for $15 \mathrm{~min}$. Pancreatic juice was collected for $90 \mathrm{~min}$. after the BPP infusion was withdrawn.

- Experiment II. After collection of basal pancreatic secretion for $1 \mathrm{hr}$. (as in experiment I), porcine secretin (Gastrointestinal Hormones Research Unit, Karolinska Institutet) was added to the saline (1.5 Ivy Dog Unit/kg body weight/hr.) and infused into the right jugular vein for $105 \mathrm{~min}$. Fifteen minutes after the beginning of secretin infusion, BPP (Eli Lilly Laboratories, lot 615-D63-166-7) was dissolved in saline and infused into the left jugular vein $(10 \mu \mathrm{g} / \mathrm{kg}$ body weight $/ \mathrm{hr}$.) for $15 \mathrm{~min}$.

Analysis. - On each thawed sample of pancreatic juice we measured total proteins, amylase and calcium. The proteins were measured by Biuret's colorimetric reaction, adapted to a Technicon autoanalyser (Michel, unpublished data). For the amylase assay, we used a volume of pancreatic juice reacting with a starch solution for 
a given length of time in a water bath at $39^{\circ} \mathrm{C}$. The sugars released after incubation were extracted by $85^{\circ}$ alcohol and measured by the sulphuric orcinol method (Besle, 1974). Calcium was measured by atomic absorption spectrophotometry (Perkin Elmer 420 ), and plasma glucose was also analyzed using the glucose-oxydase fechnique (Michel, 1971).

In order to correct any individual variations of pancreatic juice in the animals, the results were expressed as a percentage of those obtained before each infusion. Each animal thus served as its own control and the significance of the differences between the values was computed by the Student's i test.

\section{Results.}

When infused alone, BPP significantly decreased $(P<0.01)$ the excretion of water $(-51 \pm 11$ p. 100$)$, proteins $(-75 \pm 10$ p. 100), amylase $(-51 \pm 9$ p. 100) and calcium $(-45 \pm 15$ p. 100) in the pancreatic juice between the 15 th and 30 th minute after the infusion was withdrawn (fig. 1).
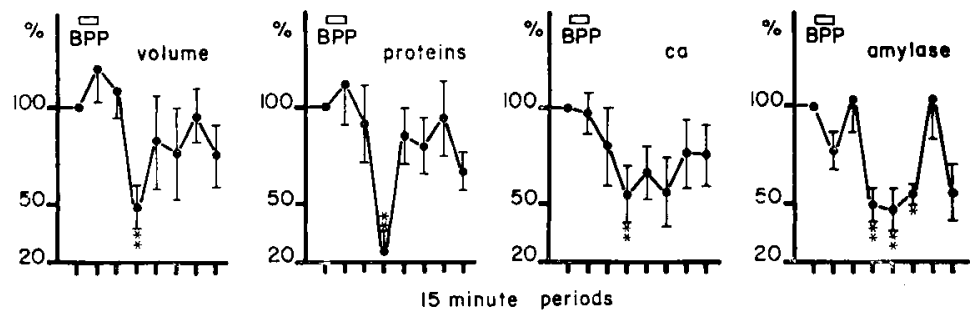

FIG. 1. - The effect of Bovine Pancreatic Polypeptide (BPP) on pancreatic juice flow rate (volume), and on proteins, amylase and calcium ( $\mathrm{Ca}$ ) pancreatic excretion in 5 calves (mean $\pm \mathrm{SEM}$ ). Results are expressed as a percentage of the initial values $(* P<0.05 ; * * P<0.01)$.

The infusion of porcine secretin significantly increased $(P<0.01)$ the flow of pancreatic juice ( $+90 \pm 10$ p. 100) during the first $15 \mathrm{~min}$. after the infusion began (fig. 2). When BPP was given simultaneously with secretin, the flow of pancreatic juice
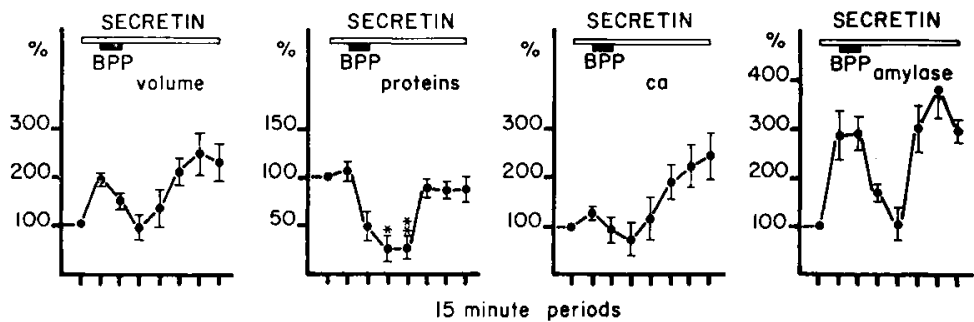

FIG. 2. - The effect of Bovine Pancreatic Polypeptide (BPP) on pancreatic juice flow rate (volume) and on proteins, amylase and calcium ( $\mathrm{Ca}$ ) pancreatic excretion, induced by secretin in 5 calves (mean \pm SEM). Results are expressed as a percentage of the initial values. $\left({ }^{*} P<0.05 ;{ }^{* *} P<0.01\right.$ I: values obtained during secretin infusion were compared with those obtained when secretin and BPP were infused together). 
decreased significantly $(-90 \pm 30$ p. $100 ; P<0.05)$ concomitantly with the pancreatic excretion of proteins $(-75 \pm 15$ p. $100 ; P<0.05)$ and amylase $(-90 \pm 20$ p. 100 ; $P<0.05)$. Forty-five minutes after the BPP was stopped, secretin infusion significantly increased pancreatic excretion of water $(+100<40$ p. $100 ; P<0.05)$ and amylase $(+300 \pm 50$ p. $100 ; P<0.01)$ (fig. 2$)$.

The infusion of BPP, whether given alone or together with secretin, had no significant influence on plasma glucose and calcium levels.

\section{Discussion.}

Very little is known of the physiology of PP, and its biological action varies among species. In birds, avian PP stimulates hepatic glycogenesis, gastric acid secretion (Hazelwood et al., 1973) and the release of glucagon (Langslow and Hazelwood, 1975). Furthermore, avian PP inhibits glucagon-stimulated lipolysis within the chicken adipocyte and causes a marked reduction in glucagon-stimulated cyclic AMP accumulation, suggesting that avian PP interferes with the glucagon-sensitive adenylate cyclase system (McCumbee and Hazelwood, 1977).

BPP injections $(2.5 \mu \mathrm{g} / \mathrm{kg}$ body weight/day for 12 to 13 days) reduce food intake and suppress body weight gain in hyperphagic obese mice (Malaisse-Lagae et al., 1977).

In dogs, the radioimmunoassayable level of pancreatic peptide in plasma (using antisera to human PP) was increased by feeding and fease feeding (Chance et al., 1975). This increase was suppressed by somatostatin (Kayasseh ef al., 1978). In man, human plasma PP level increased after protein or fat ingestion (Adrian et al., 1977). In gastrectomized men, somatostatin infusion induced a significant decline of fasting plasma HPP levels, and completely abolished human PP response to oral glucose (Marco, Hedo and Villanueva, 1977).

On the other hand, BPP enhances gastric emplying and small intestinal transit in rats, and initially stimulates and then inhibits the motility of the pylorus, duodenum, ileum, ileocecal sphincter, and colon of cats and dogs (Lin et al., 1977).

In dogs with chronic bile, gallbladder and choledochus fistulae, BPP infused intravenously at 0.125 to $5.0 \mathrm{\mu g} / \mathrm{kg} / \mathrm{hr}$, relaxed the gallbladder and increased the tonus of the choledochus without affecting bile secretion (Lin and Chance, 1974). Furthermore, in dogs with both a gastric fistula and Heindenhain's pouch, or with a pancreatic and a gastric fistula, BPP ( $40 \mu \mathrm{g} / \mathrm{kg} \mathrm{b.} w$. $/ \mathrm{hr}$.) intravenously stimulated gastric acid secretion when given alone but inhibited the submaximal secretion induced by the C-terminal pentapeptide of gastrin. Basal pancreatic secretion of dogs was inhibited by BPP (1 to $10 \mu \mathrm{g} / \mathrm{kg} / \mathrm{hr}$.). In these animals, stimulated by secretin alone, BPP (1 to $50 \mu \mathrm{g} / \mathrm{kg} / \mathrm{hr}$.) inhibited pancreatic protein secretion but often showed a biphasic action on water bicarbonate response : an initial augmentation followed by reduction. BPP (2 to $5 \mu \mathrm{g} / \mathrm{kg} / \mathrm{hr}$.) inhibited pancreatic waterbicarbonate and protein secretions induced by an infusion of secretin plus cholecystokinin (Lin et al., 1977).

In 5 men who received a 3-hr. infusion of secretin $(0,15$ clinical units $/ \mathrm{kg}$ body weight $/ \mathrm{hr}$.), to which pancreatic polypeptide $(200 \mathrm{pmol} / \mathrm{kg}$ body weight $/ \mathrm{hr}$.) was added in the middle hour, total duodenal juice protein fell $68 \pm 7$ p. 100 (Bloom et al., 1978). 
Thus, in calves as in humans and dogs, BPP seems able to regulate pancreatic exocrine secretion. This hypothesis is strengthened by the fact that in our experiments we used bovine pancreatic polypeptide, whose effects have never before been reported in the bovine species.

In this species, BPP seems to play a role in the regulation of pancreatic exocrine secretion. Our results do not allow us to ascertain whether the effects observed in calves are physiological rather than pharmacological since plasma BPP levels have yet to be determined.

Commission CNERNA Digestion-Absorption/Association des Physiologistes, Paris 5-6 octobre 1978.

Acknowledgments. - The BPP used in this experiment was kindly supplied by Dr. T. M. Lin (Lilly Research Laboratories).

Résumé. Cinq veaux mâles Holstein $\times$ Frisons, nourris avec un lait de remplacement âgés de 20 à 30 jours, pesant $66 \pm 6 \mathrm{~kg}$, porteurs d'un cathéter réentrant (implanté de façon chronique à l'âge de 10 jours) sur le canal pancréatique, à jeun depuis $16 \mathrm{~h}$ avant le début de chaque perfusion ont été utilisés au cours de 2 expériences successives.

Dans l'expérience I, la perfusion intraveineuse de BPP $(10 \mu \mathrm{g} / \mathrm{kg} P$. $V . / \mathrm{h}$, pendant $15 \mathrm{~min}$ ) provoquait une diminution significative du débit pancréatique (- $51 \pm 11 \mathrm{p} .100)$, de l'excrétion des protéines $(-75 \pm 10$ p. 100), d'amylase $(-51 \pm 9$ p. 100) et de calcium ( $-54 \pm 15$ p. 100) dans le suc pancréatique, entre la $15^{\mathrm{e}}$ et la $30^{\mathrm{e}} \mathrm{min}$ suivant la fin de la perfusion.

Dans l'expérience II, réalisée 5 jours après la précédente, sur les mêmes animaux, la même dose de BPP administrée par voie I. V. entre la $15^{\mathrm{e}}$ et la $30^{\mathrm{e}} \mathrm{min}$ d'une perfusion IV de sécrétine (1,5 Unité Chien lvy $/ \mathrm{kg} / \mathrm{h}$, pendant $105 \mathrm{~min}$ ) inhibait significativement la stimulation de l'excrétion pancréatique d'eau, de protéines et d'amylase, induite par la sécrétine.

Au cours des 2 expériences le BPP n'avait aucun effet significatif sur la glycémie des animaux.

\section{References}

ADRIAN T. E., BESTERMAN H. S., MALLINSON C. N., CZYAKOWSKA W. M., BLOOM S. R., 1977. Studies on the release of pancreatic polypeptide and its relationship to pancreatic exocrine function. J. Endocr., 75, 35P-36P.

BESLE J. M., 1974. Séparation des oses, des di- et triholosides par chromatographie d'échange d'ions. Ann. Biol. anim. Bioch. Biophys., 14, 545-573.

BLOOM S. R., ADRIAN T. E., GREENBERG G. R., BESTERMAN H. S., MC CLOY R. F., CHADWICK V. S., BARON J. M., MALLINSON C. N., BARNES A. J., ALBERTI K. G. M. M., 1978. Effects of pancreatic polypeptide infusion in man. Gostroenterology, 74, 1012 (abstr.).

CHANGE R. E., LIN T. M., JOHNSON M. D., MOON N. E., EVANS D. C., 1975. Studies on a new recognized pancreatic hormone with gastrointestinal activities. Ann. Meet. Endocr. Soc., 57th, 183.

CORRING T., 1974. Régulation de la sécrétion pancréatique par rétro-action négative chez le porc. Ann. Biol. anim. Bioch. Biophys., 14, 487-498.

DAVICCO M. J., 1978. Régulation du pancréos exocrine du jeune veau. Thèse Doct. Spécial. Univ. Clermont II, no 542, 102 PP.

DAWSON J. B., HEATON E. W., 1961. The determination of magnesium in biological materials by atomic absorption photometry. Biochem. J., 80, 99-106.

HAZELWOOD R. L., TURNER S. D., KIMMEL J. R., POLLOCK H. G., 1973. Spectrum effects of at new polypeptide (third hormone?) isolated from the chicken pancreas. Gen. comp. Endocrinol., 21, 485-497. 
KAYASSEH L., HAECKI W. H., GYR K., STALDER G. A., RITTMANN W. W., HALTER F., GIRARD J., 1978. The endogenous release of pancreatic polypeptide by acid and meal in dogs. Scand., J. Gastroent., 13, 385-391.

KIMMEL J. R., POLLOCK H. G., HAZELWOOD R. L., 1971. A new pancreatic polypeptide hormone Feder. Proceed., 30, 1318 (abstr.).

LANGSLOW D. R., HAZELWOOD R. L., 1975. Physiological action of avian pancreatic polypeptide (APP). Diabetologia, 11, 357.

LARSSON L. I., SUNDLER F., HAKANSON R., 1976. Pancreatic polypeptide. A postulated new hormone : identification of its cellular storage site by light and electron microscopic immunocytochemistry. Diabetologia, 12, 211-226.

LIN T. M., CHANCE R. E., 1974. Candidate hormones of the gut. VI. Bovine pancreatic polypeptide (BPP) and avian pancreatic polypeptide (APP). Gastroenterology, 67, 730-755.

LIN T. M., CHANCE R. E., EVANS D. C., 1973. Stimulatory and inhibitory actions of a bovine pancreatic peptide (BPP) on gastric and pancreatic secretions of dogs. Gastroenterology, 64, 865 (abstr.).

LIN T. M., EVANS D. C., CHANCE R. E., SPRAY G. F., 1977. Bovine pancreatic peptide : action on gastric and pancreatic secretion in dogs. Amer. J. Physiol., 232, E311-E315.

MALAISSE-LAGAE F., CARPENTIER J.-L., PATEL Y. C., MALAISSE W. J., ORCI L., 1977. Pancreatic polypeptide : a possible role in the regulation of food intake in the mouse. Hypothesis. Experientia, 33, 915-916.

MARCO J., HEDO J. A., VILLANUEVA M. L., 1977. Inhibitory effect of somatostatin on human pancreatic polypeptide secretion. Life Sci., 21, 789-792.

MCCORMICK R. J., STEWART W. E., 1967. Pancreatic secretion in the bovine calf. J. dairy Science, 50, 568-571.

MCCUMBEE W. D., HAZELWOOD R. L., 1977. Biological evaluation of the third pancreatic hormone (APP) : hepatocyte and adipocyte effects. Gen. comp. Endocrinol., 33, 518-525.

MICHEL M. C., 1971. Analyse quantitative de quelques substances azotées et glucidiques en milieu biologique. Essai de rationalisation. Thèse Doct. Univ., Clermont-Ferrand, no 43.

SCHWEISTHAL M. R., SCHWEISTHAL J. V., FROST C. C., 1978. Localization of human pancreatic polypeptide in an argyrophilic fourth cell type in islets of the rat pancreas. Am. J. Anat., 152, 257-262. 